\title{
Conventional versus Ritual Slaughter-Ethical Aspects and Meat Quality
}

\author{
Jagoda Żurek ${ }^{1}$, Mariusz Rudy ${ }^{1, *(\mathbb{D})}$, Magdalena Kachel ${ }^{2}{ }^{\mathbb{D}}$ and Stanisław Rudy ${ }^{3}$ \\ 1 Department of Agricultural Processing and Commodity Science, Institute of Food and Nutrition Technology, \\ College of Natural Sciences, University of Rzeszow, Zelwerowicza 4 St., 35-601 Rzeszów, Poland; \\ jzurek@ur.edu.pl \\ 2 Department of Machinery Exploitation and Management of Production Processes, University of Life Sciences \\ in Lublin, Głęboka 28 St., 20-612 Lublin, Poland; magdalena.kachel@up.lublin.pl \\ 3 Department of Thermal Technology and Food Process Engineering, University of Life Sciences in Lublin, \\ Głęboka 31 St., 20-612 Lublin, Poland; stanislaw.rudy@up.lublin.pl \\ * Correspondence: mrudy@ur.edu.pl; Tel.: +48-(0)-17-785-52-60
}

check for updates

Citation: Żurek, J.; Rudy, M.; Kachel, M.; Rudy, S. Conventional versus Ritual Slaughter-Ethical Aspects and Meat Quality. Processes 2021, 9, 1381. https://doi.org/10.3390/pr9081381

Academic Editor: Péter Sipos

Received: 14 July 2021

Accepted: 31 July 2021

Published: 8 August 2021

Publisher's Note: MDPI stays neutral with regard to jurisdictional claims in published maps and institutional affiliations.

Copyright: (c) 2021 by the authors. Licensee MDPI, Basel, Switzerland. This article is an open access article distributed under the terms and conditions of the Creative Commons Attribution (CC BY) license (https:// creativecommons.org/licenses/by/ $4.0 /)$.

\begin{abstract}
Social pressure on increased protection and welfare of animals results mainly from the initiative of people living in the urbanized parts of the world. The respect for the right to freedom of religion, which is indisputably one of the fundamental liberal rights, must be taken into account. The right to freedom to religion also includes the right to follow a religion's dietary recommendations. The aim of the literature analysis was to systematize the knowledge on the ethical aspects and quality of meat obtained from carcasses of animals subjected to conventional and ritual slaughter. Consistent with the importance of ritual slaughter for humans of two major faiths (Islam and Judaism), it is important that scientists be objective when evaluating these practices from an animal welfare and meat quality point of view. To evaluate the welfare of the slaughtered animal, it is necessary to openly discuss ritual slaughter and the improvement of its methods. The quality of meat and the degree of bleeding of animals do not always correlate with the ritual slaughter method used.
\end{abstract}

Keywords: conventional slaughter; ritual slaughter; meat quality; kosher; halal

\section{Introduction}

Meat in the human diet is a source of wholesome, easily digestible proteins, highenergy fat, vitamins-especially from the B group, as well as micronutrients necessary in metabolic processes in the human body [1]. The bioavailability of selected ingredients in meat is much higher than in food of plant origin [2,3].

In the last dozen or so years, particular attention has been paid to animal welfare, consumer health safety and environmental protection. [1]. Economic, cultural and religious conditionings of the inhabitants also are important.

There are many methods of slaughter that are required for religious and cultural reasons. Two of them, commercially significant, are halal and kosher slaughter, used by Muslims and Jews, respectively. Global trade in red meat obtained from animals slaughtered using the above-mentioned methods is significant and is growing $[4,5]$. For this reason, technologies have been developed over the years to support the commercial production of halal and kosher red meat, and regulatory and certification bodies have been established to ensure compliance with religious requirements [6-8].

In the era of rapid internationalization of trade, as a result of the advancing globalization processes, developed logistics systems ensure efficient and fast transport of goods over long distances. The possibility of selling products on a given market is determined by signed trade agreements between countries or by membership of a specific organization of countries, and the criteria determining the competitiveness of a product are primarily price and quality [9]. 
During the slaughter of animals (regardless of its type), hygienic and economic factor and humane factor need to be taken in account. The first, i.e., hygienic and economic, consists in quick and sufficient bleeding, which on the one hand guarantees quick death of the animal, and on the other hand, ensures greater durability of the meat by creating conditions for the proper course of various post-slaughter processes, improving the taste and technological values of meat [10]. Correct bleeding of carcasses is the main requirement for raw meat in order to maintain its quality. Meat from improperly bled animals is an excellent medium for microbial growth, and it can also have an unpleasant appearance [11,12].

Animal welfare science is a relatively young and rapidly growing discipline. Animal welfare can have a significant economic impact in some industries, such as food production $[13,14]$.

Meat consumers increasingly demand that animals should be bred, transported and slaughtered using humane practices [15]. Social pressure on increased protection and welfare of animals results mainly from the initiative of people living in the urbanized parts of the world [16]. Concern for animal welfare depends largely on whether people believe that animals can experience pain and suffering when mistreated [17]. One of the most important factors in determining whether an establishment has good or bad animal welfare practices is the attitude of the management staff [18,19].

On the other hand, respect for the right to freedom of religion, which is indisputably one of the fundamental liberal rights, must be taken into account. These rights include the right to follow a religion's dietary recommendations. The reason why the traditional practice of ritual slaughter is considered so important is that the practice underlies the Jewish and Muslim communities touching a fundamental part of these religions, i.e., feeding in a consistent manner with the most important convictions [20].

The aim of the literature analysis was to systematize the knowledge on the ethical aspects and quality of meat obtained from carcasses of animals subjected to conventional and ritual slaughter.

\section{Comparison of the Types of Slaughter}

\subsection{Conventional versus Ritual Slaughter}

Slaughter according to Council Regulation (EC) No. 1099/2009 [21] means the killing of animals for human consumption.

Existing slaughter methods are classified as: conventional-procedures involving stunning, and religious-animals are killed by incising their necks with a sharp knife in accordance with religious percepts, or a combination of conventional and religious slaughter [22].

During slaughter, animals should be: properly housed, restrained during the slaughter process and stunned before slaughter. Animals must be restrained in an appropriate manner to spare them any avoidable pain, injury, suffering and contusions. The degree of fear is related to the breed, sex, experience of the animal and age. The animal can be calmed by the accompanying animals and operators $[23,24]$. European Union legislation makes an exception for ritual slaughter stunning provided that the slaughter takes place in a licensed slaughterhouse [21].

The basic premise of humanely killing slaughter animals is to deprive them of consciousness by stunning and then performing slaughter operations. Stunning is preceded by immobilization, which represents a method of limiting the movements of the animal in order to effectively stun or kill it. Solipeds, ruminants, pigs, poultry and rabbits are restrained in such a way to prevent pain, trauma and suffering. The limbs of animals are not restrained or suspended, except in rabbits or poultry [25]. Devices with a locked bolt, percussion devices, sticks (in the case of small batches of rabbits), carbon dioxide or electronarcosis can be used to stun animals. Animals stunned with the use of electrical or mechanical devices on their head are immobilized in such a way that the stunning effect is achieved in the shortest possible time. Head movement restriction devices can 
be used for stunning horses or cattle [25]. Stunning causes an immediate cessation of all cerebral-cortical activity related to continuous awareness [26].

An animal is presumed to be unconscious if it loses its natural standing position, is not awake, and shows no signs of positive or negative emotions such as excitement or fear. An animal's sensitivity to stimuli is essentially determined by its ability to feel pain. Lack of reflexes and reaction of animals to sound, smell, light or physical contact proves the loss of sensitivity to stimuli [21].

Bleeding out is a method of killing animals used in slaughterhouses. The death of the animal occurs as a result of ischemia of the central nervous system and as a result of cessation of its activity, which usually occurs after losing $50 \%$ of the total amount of blood in the body. However, with a rapid outflow of blood, death can occur at the loss of $30 \%$ of blood [27].

Correct bleeding removes about $80 \%$ of the blood from the carcass. If more blood is left in the carcass, it increases the weight of the carcass, but at the same time significantly reduces the shelf life of the culinary meat [28].

The purpose of bleeding animals for slaughter is to obtain valuable raw materials with high technological parameters, whose levels are directly related to the degree of bleeding. Bleeding is a complex process that is an integral part of slaughter, and its course and effects are influenced by numerous genetic and environmental factors, as well as their interaction $[27,29,30]$.

Immediate bleeding is an important part of each type of slaughter. Blood is removed from carcasses, which in terms of extending meat shelf life and hygiene best suits human needs. Incomplete bleeding of animals may have a negative impact on meat acceptability, appearance and shelf life [31]. In the case of standard slaughter, the heart stops working earlier, which worsens the bleeding process [10].

Both Islam and Judaism have guidelines for food preparation and diet in their holy books [32-35]. Halal and kosher products are essential parts of the food industry. Hussaini [36] emphasized that halal and kosher foods are two different entities with different meanings and spirituality, although often non-Muslim consumers assume that kosher is similar to halal.

Traditional ritual slaughter without stunning animals was considered by most Muslims to be extremely important, having the highest spiritual quality [37], since the method was practiced by Prophet Muhammad and the earlier biblical prophets. Jewish consumers also identify with meat obtained from ritual slaughter (kosher meat) - meat obtained in accordance with the dietary guidelines established by traditional Jewish law [38].

Jews and Muslims are forbidden to eat blood; therefore their methods of slaughtering animals are aimed at maximum bleeding [39,40]. For Judaism and Islam, the method of slaughter is common in terms of cutting the neck and avoiding to cut the spinal cord of the animal at the beginning of slaughter [41].

Some promoters of ritual slaughter have argued that blood loss from stunning may be difficult because of cardiovascular, neurological, and vascular changes. Some reasons for this claim come from biblical laws and the Koran [42].

Many research authors have tried to resolve this issue in the past, but without any clear conclusions. Nevertheless, there are reports of more effective bleeding after kosher slaughter compared to the one with a bolt [43].

Kalweit et al. [44] did not note any differences in the relative level of haemoglobin in different muscles in the aftermath of captive bolt stunning and Shechita (slaughtering animals without prior stunning for food production, according to Jewish tradition) in calves and sheep. Moreover, in Kotula and Helbacka [45] research the method of slaughter made no difference on the amount of blood lost after neck cutting in broilers. There was no difference in the amount of retained blood in different cuts. Anil et al. [46] compared the Muslim slaughter method in sheep without stunning, with pre-slaughter stunning using a captive bolt or by electrical methods and concluded that bleed-out is not improved by a neck cut without stunning and also is not adversely affected by stunning. Similar studies 
were carried out on cattle and the same conclusions were shown [47]. Cattle that were not stunned bled up to $25 \%$ blood loss in $17.3 \mathrm{~s}$ compared to stunned animals, which bled $25 \%$ in $10.6 \mathrm{~s}$. The differences were no longer statistically significant with respect to the time the animals bled up to 50,75 and $90 \%$ of their total blood loss [47].

Table 1 presents selected parameters of blood and meat of animals depending on the type of slaughter.

Table 1. Selected parameters of blood and meat of animals depending on the type of slaughter.

\begin{tabular}{|c|c|c|c|c|c|}
\hline \multirow[b]{2}{*}{ Specification } & \multirow[b]{2}{*}{ Animal Species } & \multicolumn{3}{|c|}{ Type of Slaughter } & \multirow[b]{2}{*}{ Reference } \\
\hline & & $\begin{array}{l}\text { Conventional } \\
\text { Slaughter }\end{array}$ & $\begin{array}{c}\text { Halal } \\
\text { Slaughter }\end{array}$ & $\begin{array}{l}\text { Kosher } \\
\text { Slaughter }\end{array}$ & \\
\hline $\begin{array}{l}\text { Plasma Cortisol } \\
\text { [nmol/L] } \\
\text { Exsanguination }\end{array}$ & Cattle & 43.72 & 88.81 & & [48] \\
\hline $\begin{array}{l}\text { Plasma Cortisol [nmol/L] } \\
\text { Exsanguination } \\
\text { Plasma dopamine [ng/L] } \\
\text { Exsanguination } \\
\text { Plasma norepinephrine } \\
\text { [ng/L] Exsanguination } \\
\text { Plasma epinephrine [ng/L] } \\
\text { Exsanguination }\end{array}$ & Cattle & $\begin{array}{l}513.87 \\
3425.57\end{array}$ & & $\begin{array}{c}68.70 \\
868.43 \\
3776.20\end{array}$ & [49] \\
\hline
\end{tabular}

Plasma concentrations of

adrenaline

affected by:

- head-only electrical stunning

651

using water bath,

- slaughtering of stunned

chickens,

- slaughtering of no stun

chickens

Plasma concentrations of

noradrenaline

affected by:

- head-only electrical stunning

using water bath,

- slaughtering of stunned

chickens,

- slaughtering of no stun

chickens

Plasma concentrations of

corticosterone

affected by:

- head-only electrical stunning

using water bath,

- slaughtering of stunned

chickens,

- slaughtering of no stun chickens 
Table 1. Cont.

\begin{tabular}{|c|c|c|c|c|c|}
\hline \multirow[b]{2}{*}{ Specification } & \multirow[b]{2}{*}{ Animal Species } & \multicolumn{3}{|c|}{ Type of Slaughter } & \multirow[b]{2}{*}{ Reference } \\
\hline & & $\begin{array}{l}\text { Conventional } \\
\text { Slaughter }\end{array}$ & $\begin{array}{c}\text { Halal } \\
\text { Slaughter }\end{array}$ & $\begin{array}{l}\text { Kosher } \\
\text { Slaughter }\end{array}$ & \\
\hline $\begin{array}{l}\text { Hemoglobin, } \\
\text { Myoglobin, } \\
\text { Total heme of longissimus } \\
\text { lumborum muscle } \\
\text { [mg/100 g] }\end{array}$ & & $\begin{array}{c}0.897 \\
334.371 \\
336.267 \\
\text { (Pre-slaughter } \\
\text { anesthesia with } \\
\text { halothane followed by } \\
\text { exsanguination) }\end{array}$ & $\begin{array}{c}0.851 \\
337.196 \\
339.049\end{array}$ & & \\
\hline $\begin{array}{l}\text { Lipid oxidation } \\
\text { (mg MDA/kg meat) during } \\
\text { postmortem aging periods } \\
\text { (day): } \\
0, \\
1, \\
7\end{array}$ & & $\begin{array}{c}0.458 \\
0.561 \\
1.149 \\
\text { (Pre-slaughter } \\
\text { anesthesia with } \\
\text { halothane followed by } \\
\text { exsanguination) }\end{array}$ & $\begin{array}{l}0.498 \\
0.538 \\
1.139\end{array}$ & & \\
\hline $\begin{array}{l}\mathrm{pH} \text { of the meat }(24 \mathrm{~h}) \\
\text { Blood loss [\%] } \\
\text { Colour of the meat [pts] }\end{array}$ & Sheeps & $\begin{array}{l}6.2 \\
4.22\end{array}$ & $\begin{array}{c}6.6 \\
\text { (Muslim } \\
\text { slaughter } \\
\text { method) } \\
5.7 \\
\text { (Muslim } \\
\text { slaughter } \\
\text { method) } \\
3.98 \\
\text { (Muslim } \\
\text { slaughter } \\
\text { method) } \\
2.8\end{array}$ & & {$[46]$} \\
\hline $\begin{array}{l}\mathrm{pH} \text { of the meat }(45 \mathrm{~min}) \\
\mathrm{pH} \text { of the meat }(24 \mathrm{~h}) \\
\text { Colour of the meat [pts] } \\
\text { Blood loss }[\mathrm{kg}] \\
\text { Blood loss as a \% of live } \\
\text { weight }\end{array}$ & Cattle & $\begin{array}{c}7.06 \\
6.20 \\
4.80 \\
10.89 \\
3.10\end{array}$ & $\begin{array}{c}7.01 \\
6.17 \\
4.91 \\
10.85 \\
2.99\end{array}$ & & {$[47]$} \\
\hline $\begin{array}{l}\text { The content of minerals of } \\
\text { longissimus thoracis muscle } \\
{[\mathrm{mg} / 100 \mathrm{~g}]} \\
\mathrm{K} \\
\mathrm{P} \\
\mathrm{Na}\end{array}$ & Cattle & $\begin{array}{c}346.69 \\
200.47 \\
40.27\end{array}$ & & $\begin{array}{l}284.62 \\
182.19 \\
606.78\end{array}$ & [51] \\
\hline $\begin{array}{l}\text { Drip loss }(\%) \text { of the meat after: } \\
24 \mathrm{~h} \\
2 \text { days } \\
6 \text { days }\end{array}$ & Cattle & $\begin{array}{l}2.01 \\
2.83 \\
7.54\end{array}$ & $\begin{array}{c}5.62 \\
\text { (Islamic ritual } \\
\text { method of } \\
\text { slaughter) } \\
5.67 \\
\text { (Islamic ritual } \\
\text { method of } \\
\text { slaughter) } \\
1.12 \\
1.82 \\
4.81 \\
\text { (Islamic ritual } \\
\text { method of } \\
\text { slaughter) }\end{array}$ & & [52] \\
\hline
\end{tabular}


Table 1. Cont.

\begin{tabular}{|c|c|c|c|c|c|}
\hline \multirow[b]{2}{*}{ Specification } & \multirow[b]{2}{*}{ Animal Species } & \multicolumn{3}{|c|}{ Type of Slaughter } & \multirow[b]{2}{*}{ Reference } \\
\hline & & $\begin{array}{c}\text { Conventional } \\
\text { Slaughter }\end{array}$ & $\begin{array}{c}\text { Halal } \\
\text { Slaughter }\end{array}$ & $\begin{array}{l}\text { Kosher } \\
\text { Slaughter }\end{array}$ & \\
\hline $\begin{array}{l}\text { Colour of the meat (after } 2 \text { h) } \\
L^{*} \\
a^{*} \\
b^{*} \\
\text { Colour of the meat (after } \\
2 \text { days) } \\
L^{*} \\
a^{*} \\
b^{*}\end{array}$ & & $\begin{array}{l}46.19 \\
23.85 \\
12.43\end{array}$ & $\begin{array}{c}44.53 \\
23.85 \\
11.7 \\
\text { (Islamic ritual } \\
\text { method of } \\
\text { slaughter) } \\
44.96 \\
24.64 \\
12.58 \\
\text { (Islamic ritual } \\
\text { method of } \\
\text { slaughter) }\end{array}$ & & \\
\hline $\begin{array}{l}\text { Colour of the meat } \\
\text { non-koshered/koshered } \\
\mathrm{L}^{*} \\
\mathrm{a}^{*} \\
\mathrm{~b}^{*} \\
\mathrm{pH} \text { of the } \\
\text { non-koshered/koshered meat } \\
\text { Salt content }(\%) \text { of the } \\
\text { non-koshered/koshered meat } \\
\text { log (Total count CFU/g) of the } \\
\text { non-koshered/ko-shered } \\
\text { meat }\end{array}$ & Cattle & & & $\begin{array}{c}5.79 / 5.90 \\
0.28 / 1.47 \\
4.6 / 3.9\end{array}$ & [53] \\
\hline $\begin{array}{l}\mathrm{pH} \text { of the control sample of } \\
\text { the meat } \\
\text { (nontreated)/koshered meat: } \\
\text { Day } 0 \\
\text { Day } 14 \\
\text { Colour of the control sample } \\
\text { of the muscle } \\
\text { (nontreated)/koshered } \\
\text { External surface } \\
\text { Day } 0 \\
\mathrm{~L}^{*} \\
\mathrm{a} \text { * } \\
\mathrm{b}^{*} \\
\text { Colour of the control sample } \\
\text { of the muscle } \\
\text { (nontreated)/koshered } \\
\text { External surface } \\
\text { Day } 14 \\
\mathrm{~L}^{*} \\
\mathrm{a}^{*} \\
\mathrm{~b}^{*}\end{array}$ & Cattle & & & $\begin{array}{c}39.3 / 33.9 \\
17.4 / 13.8 \\
6.1 / 7.3\end{array}$ & [54] \\
\hline
\end{tabular}

Zulkifli et al. [50] examined stress-related hormones (adrenaline, noradrenaline and corticosterone) in broiler chickens after: lairaging, shackling, stunning, slaughtering of stunned chickens and slaughtering of no stun chickens. The animals were halal slaughtered without stunning and with electric stunning of the head in a water bath. The researchers showed that both the plasma levels of epinephrine and corticosterone during the stunning were statistically significantly higher than in the other samples. Moreover, higher values of norepinephrine were found in the plasma after stunning of chickens, compared to the 
value of this feature determined in the blood plasma after slaughter of the stunned and unstunned animals, but these differences were no longer statistically significant.

The color of meat is considered to be one of the most important quality characteristics, if it is not accepted by the consumer, all other quality characteristics assessed visually will not be relevant. Factors influencing the color of meat are, among others: the amount, composition and changes in pigments, including myoglobin $(\mathrm{Mb})$ [55]. Fresh meat myoglobin exists in three redox forms as: deoxymyoglobin $(\mathrm{DMb})$, oxymyoglobin $(\mathrm{OMb})$ and metmyoglobin $(\mathrm{MMb})$. Desoxymyoglobin is a purplish red pigment which occurs when iron is in the form of $\mathrm{Fe}^{2+}$. In the presence of molecular oxygen, deoxymyoglobin is oxidized to oxymyoglobin, giving the meat a light pink red color. In the case of oxidation of myoglobin to the $\mathrm{Fe}^{3+}$ form, the dye changes into the brown-colored metmyoglobin form $[56,57]$.

In fresh meat, the mutual ratio of the three forms of myoglobin ( $\mathrm{DMb}, \mathrm{OMb}, \mathrm{MMb})$ and the color of the meat depend on the partial pressure of oxygen and the reducing activity of the meat. Regardless of the oxygen pressure, there is a constant transformation of myoglobin into the form of metmyoglobin, and the reducing activity of meat allows the dye to be reduced to the form of oxymyoglobin (in the presence of oxygen) or deoxymyoglobin (in the absence of oxygen) [58]. Anil et al. [47] determined the color of beef on the basis of color photographic standards, animals slaughtered by halal and with captive bolt stunning and neck cutting. For the first group, the values were 4.91 points, while for the second group 4.80 points and were not statistically significant. On the other hand, Zuckerman and Mannheim [53] determined the color parameters of beef steaks before and after the koshering process in the CIE (Commission Internationale de l'Eclairage-International Commission on Illumination, Austria, Vienna) system. In this system, $L^{*}$ means lightness of the color, which is a spatial vector (higher values mean lighter meat, lower values mean darker meat), while $a *$ and $b *$ are trichromaticity coordinates, where positive $a *$ values correspond to red, negative values—green, positive $b^{*}$ - yellow, negative $b *$ - blue [59]. The authors showed that before koshering, the color of the meat was $12 \%$ lighter than after the kosher treatment. Moreover, in non-kosher meat, a higher proportion of red color was observed by $24 \%$ in comparison to the steaks subjected to this treatment. After the meat kosher process, researchers observed a $40 \%$ decrease in the yellow color.

Sabow et al. [22] determined residual hemoglobin and myoglobin concentrations in longissimus lumborum muscle of goats slaughtered by halal without stunning and pre-slaughter anesthesia followed by exsanguination. The researchers determined that the lack of significant differences between groups for residual hemoglobin concentration could be due to the similarity of blood loss between the two methods of slaughter. Moreover, the authors showed no statistically significant differences in the concentration of myoglobin in this muscle. The level of total heme (myoglobin + hemoglobin) in the muscle obtained from halal slaughtered animals did not differ significantly from that obtained from animals subjected to anesthesia, which could also be the result of a similar blood loss. Rudy et al. [51] determined the content of minerals in cattle muscles obtained from conventional and kosher slaughter. The authors showed that statistically significant higher amounts of potassium and phosphorus were determined in the muscles of animals from standard slaughter. Moreover, the sodium content showed statistically significant differences between cattle from standard slaughter and animals from kosher slaughter. The researchers reported that for the sodium content, more than 10-fold differences in the values between the analyzed groups result from the application of the salting process to which the muscle is subjected in kosher slaughter.

\subsection{Kosher and Halal Slaughter}

Comparing the two methods of ritual slaughter, the slaughter procedure used by Jews is perceived as more stringent [60]. Jews carry out a strict selection of animals, require detailed arrangements regarding the technical implementation and post-mortem inspection of the viscera $[37,60,61]$. The Islamic procedure is more flexible [37]. 
The animal must be alive and conscious during kosher slaughter, while halal slaughter requires the animal to be alive. Any method of stunning to render the animal insensitive to slaughter is not acceptable to Jews, and for halal slaughter, no stunning is preferred, but reversible forms of stunning are widely accepted and practiced. In addition, the halal method tolerates post-slaughter stunning to prevent uncontrolled movement following bleeding out of animals. In kosher slaughter a practicing Jew must be the slaughterer, however in the case of halal he may be a Muslim or a practicing Jew or Christian. The Jewish religion requires the use of a special knife, for each species of animal, while Muslims do not have a specific type of knife. Animal blessing during kosher slaughter is not required for every animal, unlike halal slaughter where the blessing is essential for each animal. Although in both religions the cut must be made in one stroke, any mistake in kosher slaughter renders the meat unfit for consumption, which is not the case in halal slaughter. Moreover, in order to remove any residual blood in the meat, Jews subject it to kosher treatment, while for Muslims what naturally remains in the meat is acceptable. Another significant difference is that for the Jewish religion some parts of the carcass are unfit for consumption while all edible parts remain halal [34,62].

\section{Characteristics of Ritual Slaughter}

\subsection{Kosher}

Jewish laws or dietary regulations are known as Kashrut laws, and the maintenance of kosher laws is in accordance with these laws. Kashrut is a Hebrew word that includes the concept of obeying the laws of keeping kosher. It means food or things that are legal, acceptable and authentic. The term Kasher or Kosher is used to denote permitted foods and their preparation under Jewish law. Anything that is not kosher is considered unfit for consumption by Jews [63].

Jews eat beef, mutton, veal, lamb and poultry, and they never eat pork. To be kosher, a mammal must have split hooves and must chew its cud, and it can be a domestic or wild animal. The rules on which the birds are approved for consumption have not been defined; The Bible only mentions those birds that are prohibited. To be kosher, a fish must have scales and gills, all others are not kosher [63].

The slaughter of animals and the processing of meat are carried out in accordance with rabbinical law. Pre-slaughter stunning and tissue damage-such as ecchymosis, are unacceptable. Shechita advocates reject methods of stunning animals prior to slaughter on the following grounds. Shechita is a humane method of slaughter and death is immediate, without any negative effects on animal welfare. It is a painless, perfect method, causing immediate loss of consciousness, while during stunning, carcasses are damaged [64].

Such slaughter is a ritual of killing an animal resulting from the requirements of religion, which is exemplified in Judaism by the Shechita. In order to obtain a license, a Jewish slaughterer must be a practicing worshiper and participate in a special training course on kosher slaughter [65]. This slaughter is performed by a qualified Jewish slaughterer while saying the appropriate prayer and consists in cutting the trachea, oesophagus, carotid arteries and jugular veins, with a continuous cut, not more than back and forth using a special knife, which is extremely sharp, with a straight blade at least twice the diameter of the animal's neck $[9,25,34,66]$. The neck is cut between the first and the second rings of the trachea. The cutting edge of the knife cannot touch the larynx or cervical vertebrae. Otherwise, the animal will be considered non-kosher [63].

After each slaughter, the qualified Jewish slaughterer checks the cut on the animal's neck to make sure it has been cut correctly [34]. During slaughter, the slaughterer must avoid one of five forbidden techniques (Table 2) which disqualify kosher cutting, which makes the meat unfit for consumption by Jews [65-67]. Additionally, a postmortem examination of carcasses is performed to detect changes, especially in the chest, lungs and liver. If disease symptoms are detected, the meat of such an animal cannot be considered suitable for consumption $[37,61,67]$. Depending on the lesions found in the liver and lungs, carcasses can be classified as highest quality, medium quality or inadequate [61]. 
Table 2. Five Forbidden Techniques to be Avoided in Kosher Slaughter.

\begin{tabular}{|c|c|}
\hline Forbidden Technique & Description \\
\hline Pausing & Hesitation during the incision \\
\hline Pressing & $\begin{array}{c}\text { Pressing or hacking instead of sliding, occurrence of forward } \\
\text { and backward movements }\end{array}$ \\
\hline Digging & The knife is not visible throughout the shechita \\
\hline Tearing & $\begin{array}{l}\text { Rupture of the trachea or esophagus; can happen if there is an } \\
\text { incision in the knife }\end{array}$ \\
\hline Piercing & $\begin{array}{c}\text { Cutting below upper lobe of the lung or above the large ring } \\
\text { in the trachea (when injected with air) }\end{array}$ \\
\hline
\end{tabular}

Source: [60].

After incision, the animal is raised with its neck lowered to facilitate blood drainage from the carcass and skinning. This stage also involves the removal of the sciatic nerve in the hind limb - the thigh, as it contains a lot of blood that cannot be drained [63]. In Israel, where butchers are trained, the surgery is a routine practice, but it is rare and limited in countries abroad. The process of removing the sciatic nerve is time consuming and not very profitable. For this reason, Jewish communities outside Israel prefer to avoid the backs of the carcass, which are rejected by the qualified Jewish slaughterer, even if the carcass is considered kosher [68-70].

The meat is also prepared by properly removing all large arteries and veins, and forbidden fats. In addition, the kidneys, intestines, bruised meat, coagulated blood are removed. The meat is then cleaned of blood residues through a kosher process [34,37,71].

Koshering is the last stage to be performed in the process of making the meat fit for consumption by Jewish consumers [64]. The term "koshering meat" also refers to the blessing of the animal during slaughter and the rabbi's inspection of the carcass for irregularities. If the carcass passes inspection, it will be classified as "kosher" [72,73].

The koshering process, consisting in salting, is aimed at removing blood from the meat and consists in soaking the meat in water for half an hour, then salting it with coarse salt for an hour and rinsing it three times [73]. Salt has a food preservative effect and an inhibitory effect on microbial activity [72]. In addition, it was shown that salting meat in the koshering process reduced E. coli and Salmonella [74].

One of the major problems with kosher treatment is the loss of the red color of the meat. Since high salt concentration promotes the oxidation of myoglobin molecules, meat subjected to salting treatments usually has an unattractive brown-gray color [54].

Some scientists have suggested that the blood supply to the brain during ritual slaughter is cut off quickly, causing an almost instantaneous loss of consciousness [66]. However, not all authors agree with this claim. In some animals, consciousness is prolonged for more than $60 \mathrm{~s}[75,76]$. Grandin [77] observed that near-instantaneous loss of consciousness can be induced in more than $95 \%$ of cattle if a ritual slaughterer makes a quick and deep cut close to the jaw. Further observations showed that calm cows and bulls become unconscious faster than cattle with visible signs of excitation [77].

Among all animal species, cattle remain conscious the longest after a throat slit without prior stunning. This is due to the fact that the brain of ruminants is supplied with blood by vessels of the rete mirabile. The vertebral vessels are protected in the opening of the cervical vertebrae; hence they are not cut and can supply blood to the forebrain through the vertebral-occipital anastomosis and maxillary vertebrae and the carotid-arterial network [78]. Supplying the brain with blood with these vessels is possible and confirmed, but there is no consensus as to whether the prolonged availability of oxygen and blood is sufficient to maintain consciousness [64]. In addition, cerebral blood flow following throat slits during kosher slaughter is insufficient to support brain function [66].

Stress increases blood cortisol levels and reduces muscle glycogen reserves, which may reduce postmortem lactic acid production and result in high $\mathrm{pH}$ of meat $[79,80]$. Catecholamines (dopamine, epinephrine and norepinephrine) and cortisol are released in response to stress and directly stimulate glycogen mobilization [81]. The applied method 
of slaughtering animals may affect the indicators of the stress level, playing an important role in the proper acidification of the meat [82].

Bozzo et al. [49] examined the stress indicators (cortisol and catecholamines: dopamine, epinephrine and norepinephrine) in male beef cattle at the age of eight months. The animals were divided into two groups, subjected to kosher (A) and conventional (B; after stunning by captive bolt gun) slaughter. The indicators were examined at three different stages of productive life; step 1-on the farm, step 2-after transportation and step 3-during bleeding. The authors observed the greatest difference between the two methods of slaughter during bleeding. There were statistically significant differences between all parameters except epinephrine. In animals subjected to kosher ritual slaughter, cortisol, dopamine, norepinephrine and epinephrine were at the following levels: $68.70 \pm 30.61 \mathrm{nmol} / \mathrm{L}, 868.43 \pm 508.52 \mathrm{ng} / \mathrm{L} ; 3776.20 \pm 1918.44 \mathrm{ng} / \mathrm{L}$ and $4352.20 \pm 3730.15 \mathrm{ng} / \mathrm{L}$, respectively. For animals from conventional slaughter, the values were: $45.08 \pm 14.15 \mathrm{nmol} / \mathrm{L} ; 513.87 \pm 286.32 \mathrm{ng} / \mathrm{L} ; 3425.571777 .39 \mathrm{ng} / \mathrm{L}$; and $3279.97 \pm 1954.53 \mathrm{ng} / \mathrm{L}$, respectively. Animals intended for ritual slaughter showed lower levels of cortisol and catecholamines on the farm and after transport to the slaughterhouse. The authors indicated that the animals selected by rabbis at the end of stage 1 are generally the most gentle and obedient. The results of the studies of the cited authors suggest that animals killed according to the rules of kosher slaughter are subjected to conditions of greater stress in the bleeding phase.

\subsection{Halal}

Halal from Arabic means: permitted, lawful, approved, sanctioned, legal, trustworthy or valid [83-85].

For Muslims, halal is a term that means any acceptable action under Islamic Sharia law [85]. These laws apply not only to eating and drinking, but also to listening, dressing and dealing with others (people or animals) [86].

Islamic law prescribes a set of dietary rules that list permitted food and prohibit the consumption of meat not obtained in accordance with Islamic principles, regarding the handling of animals before and during slaughter [34,87]. For Muslims, consuming only halal food is a religious obligation [85].

Halal meat must be obtained only from halal species. All land animals are halal with the exception of dogs, pigs, carnivores such as lions, tigers, cats, bears, and similar tusked animals such as elephants and animals, which are permitted to be killed in Islam, such as centipedes, scorpions, rats and other similar. Moreover, all birds are halal, with the exception of scavengers, birds of prey, that is, those with claws and feeding by tearing and snatching, like eagles and birds that are forbidden to kill in Islam (woodpeckers) [88-91].

The spiritual quality of halal meat is essential for the target consumers [37], and therefore all spiritual aspects, including animal welfare standards in the production of this meat, must be met [92]. Islamic scripture sources as well as the practices and writings of early and recent Islamic scholars, abound in directives relating to the humane treatment of animals [39,42,93].

Islam places great emphasis on the humane treatment of animals before and during slaughter. Some of the conditions include providing the animal with water and adequate rest, avoiding stressful conditions, not killing the animal in front of others of its kind, and not sharpening a knife in front of the animals. It is important to emphasize that Islam respects the inherent value of animals and teaches animal welfare [39].

Halal slaughter for adherents of the Islamic faith is important, both for economic and ethical reasons. It is conditioned by the huge demand for meat obtained from this slaughter, as well as the insistence of some Muslim groups to slaughter fully conscious animals [94]. The halal slaughter method is believed to provide significant bleeding while the heart is still beating, which may be beneficial for extending the shelf life or maintaining the quality of the meat [22].

There are three acceptable methods of slaughtering animals in Islam: 
- Slaughter: cuts the animal's trachea, esophagus and jugular veins. This method is mainly used for sheep, cattle and birds.

- Undercut: Performed by stabbing the animal with a knife at the bottom of the neck and making a cut through the front of the chest. This method is mainly used for camels.

- Stabbing: Performed by fatally injuring an animal that cannot be tamed, such as a wild animal that is allowed to be hunted, or a domestic animal that is difficult to control [95].

The method of halal slaughter is based on the interpretation of the Koran and Hadith [39]. At the moment of killing, the animal should face Mecca, while the slaughterer says the appropriate formula. Slaughter can be performed by every adult, mentally healthy, devout Muslim [96]. According to the Koran, a slaughterer may come from the people of the book (Jews and Christians), but would nevertheless have to meet all halal requirements [86]. Moreover, effective bleeding is one of the conditions for halal slaughter [47]. Since the consumption of blood is forbidden, any process affecting the removal of the maximum amount of blood during slaughter would be favored by Islamic scholars [38].

The authorities of many factions of Islam allow reversible methods of stunning animals, i.e., mechanically with a non-penetrating pin device or electrically with electrodes applied on both sides of the head or in a water bath. They can be used only after fulfilling several conditions [39]:

- the stunning equipment must be supervised by a qualified Muslim and periodically inspected by the appropriate Islamic authorities or halal certification body,

- $\quad$ stunning must be reversible, i.e., it must neither kill nor cause permanent damage to the animal,

- $\quad$ equipment used for stunning pigs must never be used for halal animals.

There is no Islamic ruling regarding the form and size of the knife to be used for halal slaughter. However, studies have shown that when slaughtered without stunning, the knife must be at least twice as long as the animal's neck [97]. Knives that are too short can cause the knife tips to go directly into the wound with a painful response, and if the knife is longer than necessary, it can cause the slaughterer to make more mistakes [98]. The knives should be well sharpened, without nicks and scrape $[10,99,100]$. Blunt knives can block the arteries of slaughtered animals, which results in slower bleeding and longterm suffering of the slaughtered animal [101]. The head should not be cut off the neck during slaughter [62]. Velarde et al. [102] reported that the length of knives dedicated to halal slaughter in different slaughterhouses varies between $22.2 \pm 1.82 \mathrm{~cm}$ for sheep, $29 \pm 1.79 \mathrm{~cm}$ for cattle and $13 \mathrm{~cm}$ for poultry.

Figure 1 shows some of the halal certification symbols used for different countries.
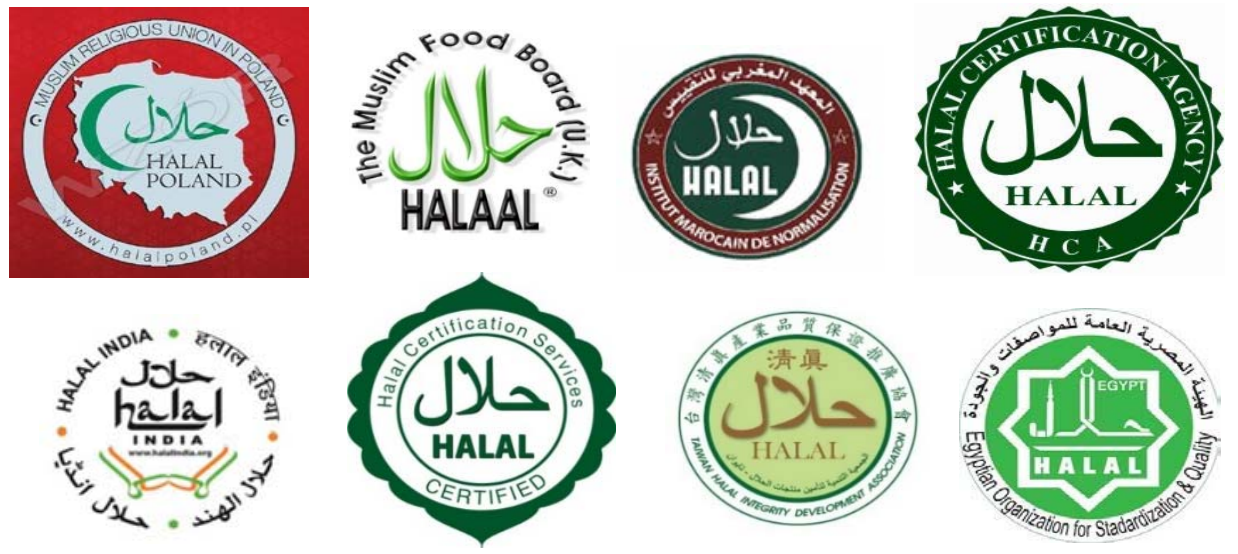

Figure 1. Some of the halal certification symbols for different countries. Source: [103]. 
A prerequisite for slaughter is a quick and effective neck cut, which has a major impact on animal welfare [104]. The exact position of cutting the neck has not been specified. Gregory et al. [105] demonstrated that making the cut in the neck at the first cervical vertebrae, instead of the second one, improved bleeding efficiency by the early arrest of blood flow and reducing the frequency of false aneurysm formation. Furthermore, false aneurism could extend the period of consciousness of slaughtered animals without pre-stunning resulting in unnecessary suffering [104].

One of the most important conditions for meat to be considered halal is that the animal must be alive at the time of slaughter. Some Muslims, however, insist that animals must be conscious at the time of slaughter. This has led to a debate among Islamic lawyers as to whether modern slaughter technologies such as pre- and post-slaughter stunning, mechanical slaughter could be accepted as part of halal slaughter. Opponents of stunning argue that this practice is contrary to Islamic Sharia law because the Prophet did not use such technology and it is possible that some animals may die as a result of stunning [94,104]. Moreover, there are concerns that this process prevents the drainage of all blood from the animal and carcass [47]. In contrast, pre-slaughter stunning advocates argue that if the procedure minimizes the pain associated with neck cutting and the method does not kill the animals before slaughter, stunning can be accepted as a halal-compliant procedure [94,104]. Table 3 shows the most suitable stunning for halal production.

Table 3. Guideline parameters for electrical stunning.

\begin{tabular}{ccc}
\hline Type of Animal & Current [Ampere] & Duration [Seconds] \\
\hline Chicken & $0.25-0.50$ & $3.00-5.00$ \\
Lamb & $0.50-0.90$ & $2.00-3.00$ \\
Goat & $0.70-1.00$ & $2.00-3.00$ \\
Sheep & $0.70-1.20$ & $2.00-3.00$ \\
Calf & $0.50-1.50$ & 3.00 \\
Steer & $1.50-2.50$ & $2.00-3.00$ \\
Cow & $2.00-3.00$ & $2.50-3.50$ \\
Bull & $2.50-3.50$ & $3.00-4.00$ \\
Buffalo & $2.50-3.50$ & $3.00-4.00$ \\
Ostrich & 0.75 & 10.00 \\
\hline
\end{tabular}

Source: [89].

Muhammad [106] reported that the slaughter of halal without stunning has been endorsed by members of the Association of Muslim Lawyers and the scientific community as being humane as it initiates massive hemorrhage and anoxia-lack of oxygen in brain cells. In this way, it acts as a powerful analgesic that turns off the sensory center and makes the animal insensitive to pain.

In the literature $[92,107,108]$ there is cited the experiment of Professor Schultz and Dr. Hazim of the University of Hanover who assessed the effectiveness of halal slaughter by using an electrocardiogram (ECG) and an electroencephalograph (EEG) to show that the Islamic slaughter method was a humane method. The animals were slaughtered using two methods - the first without stunning and the second by using captive bolt. During the first three seconds of halal slaughter without EEG stunning showed no changes in brain activity, indicating that the animal felt no pain during and immediately after cutting. During the next $3 \mathrm{~s}$, the EEG registered a state of profound unconsciousness which was probably due to the loss of large amounts of blood. After the said $6 \mathrm{~s}$, the EGG showed no brain activity. As the brain's messages were going to zero, the animal's heart was beating and the body was vibrating vigorously (a reflex action of the spinal cord), draining the maximum amount of blood from the animal's body.

Gibson et al. [109] examined the electroencephalographic responses of stunned bulls using pneumatically powered penetrating or non-penetrating captive bolt guns. The animals were divided into two groups according to the stunning method used. The authors reported that all bulls shot with penetrating captive bolt had EEG activity patterns incon- 
sistent with consciousness, while $82 \%$ of animals stunned with a non-penetrating captive bolt showed curves suggesting loss of consciousness. Moreover, in two bulls in this group, the authors found periods of normal activity and EEG maintenance or increased spectral power compared to pre-treatment values, indicating incomplete concussion. The study showed that the pneumatic penetrating captive bolt rendered all animals unconscious, while the non-penetrating captive bolt stunning was less effective. After an effective neck dissection, sheep are unconscious (EEG score) within 2-7 s [110] and cortical brain death occurs after approximately $14 \mathrm{~s}$ [111]. Rodriguez et al. [112] found that the onset of loss of consciousness in lambs may extend to $1 \mathrm{~min}$ and postulated that the difference from studies by other researchers may be due to the potential ineffectiveness of bleeding. The results of these studies show that most of the blood is lost within the first 2 min and show, in line with previous studies $[113,114]$ that the bleeding of lambs during exsanguination is completed in $2 \mathrm{~min}$. From this perspective, there is no need to provide extra bleeding time to increase blood loss [38].

In the EU countries, halal meat is produced from both stunned and non-stunned animals, in line with the EU legislation on the protection of animals at the time of killing [81].

Some researchers have suggested that slaughtering animals without stunning is as humane a method of slaughter as slaughter with stunning $[115,116]$. Nevertheless, most researchers recognize that slaughter without stunning causes unnecessary suffering and pain to animals [90].

Opponents of the initial stunning of animals in halal slaughter often give the following reasons for rejecting this procedure: the possibility of death of animals before slaughter, difficulties in identifying and removing dead animals before incising the neck, adverse effect on the speed and volume of bleeding, besides, poor quality of carcasses and meat. Studies have shown that the total amount of blood lost at slaughter does not differ significantly for animals slaughtered pre-stunned, post-stunned or slaughtered without stunning $[38,46,47,117]$. Sabow et al. [22] found that slaughtering goats following minimal anesthesia did not cause poor bleeding compared to slaughtering halal fully conscious goats and did not affect the preservation of meat quality. Önenç and Kaya [118] showed that percussive captive bolt stunning of young bulls improved meat quality in comparison with young bulls slaughtered using head-only electrical stunning and those slaughtered without stunning.

D'Agata et al. [52] compared the quality characteristics of beef obtained from halal slaughter of cattle and the standard method. The $\mathrm{pH}$ values measured after $2 \mathrm{~h}$ were lower in meat from conventional slaughter (5.55) than from ritual halal slaughter (5.62). The $\mathrm{pH}$ values slightly increased on the second day after slaughter: 5.61 and 5.67 respectively, while beef obtained from standard slaughter, during the second to the sixth day, showed greater stability of these values. At the same time, the $\mathrm{pH}$ of meat obtained from ritual slaughter increased dramatically and amounted to 5.80, which increased the risk of microbial growth and reduced shelf life. In contrast, studies by Anil et al. [47] did not show significant differences between the $\mathrm{pH}(45 \mathrm{~min})$ and $\mathrm{pH}(24 \mathrm{~h})$ of cattle slaughtered without stunning and that slaughtered using captive bolt stunning. In meat obtained from carcasses of animals from standard slaughter, a higher drip loss was found than in beef from the ritual slaughter group [52]. Meat obtained from carcasses of animals from ritual slaughter without stunning may have small red spots on its surface, which reduces its quality and may threaten its acceptability by consumers. This is due to an increase in petechial hemorrhages caused by the increased blood pressure and the breaking of the vasal endothelium, which may be related to the short-term excitation of the cattle before slaughter [52].

Barrasso et al. [48] tested two groups of male cattle aged 8 months to determine plasma cortisol values at two different times of animal productive life-on the farm, one week prior to slaughter (time 0 ) and during bleeding (time 1). The first group of animals (A) was slaughtered according to the requirements of halal slaughter without stunning. The cattle in group two (B) were subjected to conventional slaughter, by captive bolt gun stunning, which causes immediate unconsciousness rendering the animal insensitive to pain until 
death due to bleeding. The authors found lower cortisol levels measured at time 0 in group A animals $(3.26 \mathrm{nmol} / \mathrm{L})$ than in group B $(4.06 \mathrm{nmol} / \mathrm{L})$. However, the level of cortisol determined during bleeding was significantly higher in animals slaughtered according to the halal method $(88.81 \mathrm{nmol} / \mathrm{L})$ than in the group of animals subjected to conventional slaughter $(43.72 \mathrm{nmol} / \mathrm{L})$. The data showed the greatest variation between farms; time 0 , and bleeding out; time 1, in animals subjected to halal ritual slaughter, being 27.52 times higher compared to those slaughtered by the standard method, where the average growth was 12.85 of times.

\section{Conclusions}

In both types of ritual slaughter (kosher and halal), the cut must be made in one stroke, whereby any error in kosher slaughter makes the meat unfit for consumption, which is not the case in halal slaughter. Moreover, to remove the residual blood in the meat, the Jews subject the meat to a kosher treatment (special salting), while for Muslims what naturally remains in the meat is acceptable. Another significant difference is that for the Jewish religion some parts of the carcass are unfit for consumption, while all edible parts remain considered halal. Halal slaughter has been endorsed by members of the Association of Muslim Lawyers and the scientific community as humane because it initiates mass hemorrhage and anoxia-lack of oxygen in the brain cells. In this way, halal slaughter acts as a powerful analgesic that turns off the sensory center and makes the animal insensitive to pain. Ritual slaughter causes the most effective bleeding of carcasses, which from the quality and hygiene point of view best suits human needs. Meat from ritual slaughter is more durable and does not deteriorate quickly. With standard slaughter, the heart stops working earlier, which can worsen the bleeding process.

The results of studies by some authors suggest that animals killed according to the rules of kosher slaughter, compared to conventional slaughter, are subjected to conditions of greater stress in the bleeding phase (greater amount of stress hormones in the blood). In other studies, on the other hand, during the first three seconds of halal slaughter without stunning, EEG (electroencephalograph) showed no changes in brain activity, indicating that the animal felt no pain during and immediately after cutting. During the next $3 \mathrm{~s}$, the EEG registered a state of profound unconsciousness which was probably due to the loss of a large amount of blood. After $6 \mathrm{~s}$, the EGG (electrocardiogram) showed no brain activity. In non-kosher meat, the color is usually $12 \%$ lighter, and the red content is $24 \%$ higher in comparison with the steaks subjected to kosher treatment. However, after the process of koshering meat, the yellow color decreases by $40 \%$. In the muscles of animals from standard slaughter there are, among others, higher amounts of potassium and phosphorus compared to the raw material obtained from carcasses of animals from kosher slaughter, and in the case of kosher meat, a 10 times higher sodium content is observed.

The studies of some authors also show that the $\mathrm{pH}$ values measured after $2 \mathrm{~h}$ are lower in the meat of cattle from conventional slaughter (5.55) than from ritual halal slaughter (5.62). On the other hand, in meat obtained from cattle carcasses from ritual slaughter, the $\mathrm{pH}$ increases dramatically to 5.80 during the second to the sixth day, which increases the risk of development of microorganisms and shortens the shelf life, and beef obtained from standard slaughter at the same time shows greater stability of these values. In turn, in the meat of unstunned animals before slaughter, a higher water retention capacity is found, compared to that obtained from animals slaughtered in a conventional system.

Author Contributions: Conceptualization, J.Ż.; writing—original draft preparation, J.Ż.; writingreview and editing, J.Ż., M.R., M.K. and S.R.; visualization M.R. and S.R.; supervision and funding acquisition M.R. and M.K. All authors have read and agreed to the published version of the manuscript.

Funding: This research received no external funding.

Conflicts of Interest: The authors declare that they have no conflict of interest.

Ethical Statement: This study did not involve any testing on humans nor any testing on live animals. 


\section{References}

1. Pisula, A.; Pospiech, E. Mięso-Podstawy Nauki i Technologii; SGGW: Warszawa, Poland, 2011; pp. 15-21.

2. Troy, D.J.; Kerry, J.P. Consumer perception and the role of science in the meat industry. Meat Sci. 2010, 86, 214-226. [CrossRef]

3. Buzała, M.; Słomka, A.; Janicki, B. Heme iron in meat as the main source of iron in the human diet. J. Elem. 2016, 21, 303-314. [CrossRef]

4. Mintel. 3 in 5 Kosher Food Buyers Purchase for Food Quality, Not Religion. Available online: https://www.mintel.com/presscentre/food-and-drink/3-in-5-kosher-food-buyers-purchase-for-food-quality-not-religion (accessed on 1 June 2021).

5. Sunkar, I. The global halal trade, trends and issues. Halal J. 2008, 3, 32-34.

6. Farouk, M.M. New Zealand meat industry must optimise Halal market opportunities. NZ Food Technol. $2012,47,9$.

7. Weaver, A.L.; Wotton, S.B. The Jarvis Beef Stunner: Effects of a prototype chest electrode. Meat Sci. 2009, 81, 51-56. [CrossRef]

8. Longdell, G.R. Advanced technologies in the meat industry. Meat Sci. 1994, 36, 277-291. [CrossRef]

9. Mroczek, R. Ubój rytualny w Polsce-Wybrane aspekty. Zeszyty Naukowe Szkoły Głównej Gospodarstwa Wiejskiego w Warszawie Problemy Rolnictwa Światowego 2017, 17, 106-115. [CrossRef]

10. Szymborski, J. Ubój rutynowy a rytualny. Podobieństwa i różnice. Życie Weterynaryjne 2015, 90, 469-471.

11. Gregory, N.G. Animal welfare at markets and during transport and slaughter. Meat Sci. 2008, 80, 2-11. [CrossRef]

12. Nakyinsige, K.; Fatimah, A.B.; Aghwan, Z.A.; Zulkifli, I.; Goh, Y.M.; Sazili, A.Q. Bleeding efficiency and meat oxidative stability and microbiological quality of New Zealand White rabbits subjected to halal slaughter without stunning and gas stun-killing. Asian-Australas. J. Anim. Sci. 2014, 27, 406-413. [CrossRef]

13. Gallo, C.B.; Huertas, S.M. Main animal welfare problems in ruminant livestock during preslaughter operations: A South American view. Animal 2016, 10, 357-364. [CrossRef]

14. Huertas, S.; van Eerdenburg, F.; Gil, A.; Piaggio, J. Prevalence of carcass bruises as an indicator of welfare in beef cattle and the relation to the economic impact. Vet. Med. Sci. 2015, 1, 9-15. [CrossRef]

15. Bonnet, C.; Bouamra-Mechemache, Z.; Réquillart, V.; Treich, N. Viewpoint: Regulating meat consumption to improve health, the environment and animal welfare. Food Policy 2020, 97, 1-11. [CrossRef]

16. Thorton, P.K. Livestock production: Recent trends, future prospects. Philos. Trans. R. Soc. Lond. B Biol. Sci. 2010, 365, $2853-2867$. [CrossRef]

17. Dawkins, M.S. From an animal's point of view. Motivation, fitness and animal welfare. Behav. Brain Sci. 1990, 13, 1-16. [CrossRef]

18. Balzani, A.; Hanlon, A. Factors that Influence Farmers' Views on Farm Animal Welfare: A Semi-Systematic Review and Thematic Analysis. Animals (Basel) 2020, 10, 1524. [CrossRef]

19. Grandin, T. Factors that impede animal movement at slaughter plants. J.Am. Vet. Med. Assoc. 1996, $209,757-759$.

20. Zuolo, F. Equality among animals and religious slaughter. Hist. Soc. Res. 2015, 40, 110-127. [CrossRef]

21. Council Regulation (EC) No 1099/2009 of 24 September 2009 on the protection of animals at the time of killing (Text with EEA relevance). Available online: https:/ / eur-lex.europa.eu/LexUriServ/LexUriServ.do?uri=OJ:L:2009:303:0001:0030:EN:PDF (accessed on 5 July 2021).

22. Sabow, A.B.; Sazili, A.Q.; Zulkifli, I.; Goh, Y.M.; Ab Kadir, M.Z.A.; Abdulla, N.R.; Nakyinsige, K.; Kaka, U.; Adeyemi, K.D. A comparison of bleeding efficiency, microbiological quality and lipid oxidation in goats subjected to conscious halal slaughter and slaughter following minimal anesthesia. Meat Sci. 2015, 104, 78-84. [CrossRef]

23. Grandin, T. Assessment of stress during handling and transport. J. Anim. Sci. 1997, 75, 249-257. [CrossRef]

24. von Wenzlawowicz, M.; von Holleben, K. Tierschutz bei der betäubungslosen Schlachtung aus religiösen Gründen. Deutsches Tierärzteblatt 2007, 55, 1374-1386.

25. Frieske, A.; Kowaliszyn, B.; Mroczkowski, S. Legalne uśmiercanie zwierząt. Przeglad Hodowlany 2013, 5, 30-32.

26. Johnson, C.B.; Gibson, T.J.; Stafford, K.J.; Mellor, D.J. Pain perception at slaughter. Anim. Welf. 2012, 21, 113-122. [CrossRef]

27. Tereszkiewicz, K.; Choroszy, K. Wybrane aspekty wykrwawienia ubojowego tuczników. Wiadomości Zootechniczne 2017, 1, 39-47.

28. Pisula, A.; Florowski, T. Zmiany ilościowe i jakościowe mięsa w trakcie jego pozyskiwania i przetwarzania. Część II, zmiany w okresie poubojowym. Gospodarka Mięsna 2008, 3, 12-20.

29. Rybarczyk, A.; Karamucki, T.; Drozd, R.; Polasik, D.; Łupkowska, A.; Michalecka, A. Influence of selected factors upon the blood loss from the carcasses of pigs free of the stress susceptibility gene (RYR1T). Anim. Sci. Pap. Rep. 2015, 33, 177-184.

30. Tereszkiewicz, K. Przebieg i Uwarunkowania Wykrwawienia Tuczników; Oficyna Wydawnicza Politechniki Rzeszowskiej: Rzeszów, Poland, 2009.

31. Aghwan, Z.A.; Regenstein, J.M. Slaughter practices of different faiths in different countries. J. Anim. Sci. Technol. 2019, 61, 111-121. [CrossRef]

32. Eliasi, J.R.; Dwyer, J.T. Kosher and Halal: Religious observances affecting dietary intakes. J. Am. Diet. Assoc. 2002, 102, 911-913. [CrossRef]

33. Gutman, B.N. Ethical eating: Applying the kosher food regulatory regime to organic food. Yale Law J. 1999, 108, 2351-2384. [CrossRef]

34. Regenstein, J.M.; Chaudry, M.M.; Regenstein, C.E. The Kosher and Halal Food Laws. Compr. Rev. Food Sci. Food Saf. 2003, 2, 111-127. [CrossRef]

35. Qureshi, S.S.; Jamal, M.; Qureshi, M.; Rauf, M.; Syed, B.H.; Zulfiqar, M.; Chand, N. A review of Halal food with special reference to meat and its trade potential. Can. J Plant Sci. 2012, 22, 79-83. 
36. Hussaini, M.M. Islamic Dietary Concepts and Practices; Al-Meezan International, Islamic Food and Nutrition Council of America: Bedford Park, IL, USA, 1993; pp. 1-325.

37. Farouk, M.M.; Al-Mazeedi, H.M.; Sabow, A.B.; Bekhit, A.E.D.; Adeyemi, K.D.; Sazili, A.Q.; Ghani, A. Halal and Kosher slaughter methods and meat quality: A review. Meat Sci. 2014, 98, 505-519. [CrossRef] [PubMed]

38. Khalid, R.; Knowles, T.G.; Wotton, S.B. A comparison of blood loss during the Halal slaughter of lambs following Traditional Religious Slaughter without stunning, Electric Head-Only Stunning and Post-Cut Electric Head-Only Stunning. Meat Sci. 2015, 110, 15-23. [CrossRef]

39. Nakyinsige, K.; Che Man, Y.B.; Aghwan Zeiad, A.; Zulkifli, I.; Goh, Y.M.; Abu Bakar, F.; Al-Kahtani, H.A.; Sazili, A.Q. Stunning and animal welfare from Islamic and scientific perspectives. Meat. Sci. 2013, 95, 352-361. [CrossRef]

40. Brondz, I. Why Judaism and Islam Prohibit Eating Pork and Consuming Blood as a Food? Voice Publ. 2018, 4, 22-31. [CrossRef]

41. Pakeeza, S.; Munir, M. Dietary Laws of Islam and Judaism: A Comparative Study. Al-Adwa 2016, 45, 1-14.

42. Masri, B.A. Animals in Islam; The Athene Trust: Petersfield, UK, 1989; pp. 1-250.

43. Levinger, I.M. Physiological and general medical aspects of Shechita. In Shechita; Munk, M.L., Munk, E., Eds.; Gur Aryeh Publications: Jerusalem, Israel, 1976; pp. 101-214.

44. Kallweit, E.; Ellendorf, F.; Daly, C.; Smidt, D. Physiological reactions during slaughter of cattle and sheep with and without stunning. Dtsch Tierarztl Wochenschr. 1989, 96, 89-92. [PubMed]

45. Kotula, A.W.; Helbacka, N.V. Blood retained by chicken careasses and cut-up parts as influenced by slaughter method. In Proceedings of the 7th International Congress of Nutrition, Hamburg, Germany, 3-10 August 1966; pp. 404-410.

46. Anil, M.; Yesildere, T.; Aksu, H.; Matur, E.; McKinstry, J.; Erdogan, O.; Hughes, S.; Mason, C. Comparison of religious slaughter of sheep with methods that include pre-slaughter stunning, and the lack of differences in exsanguination, packed cell volume and meat quality parameters. Anim. Welf. 2004, 13, 387-392.

47. Anil, M.H.; Yesildere, T.; Aksu, H.; Matur, E.; McKinstry, J.L.; Erdogan, O.; Hughes, S.; Mason, C. Comparison of Halal slaughter with captive bolt stunning and neck cutting in cattle: Exsanguination and quality parameters. Anim. Welf. 2006, 15, 325-330.

48. Barrasso, R.; Bonerba, E.; Ceci, E.; Roma, R.; Alò, A.; Mottola, A.; Marchetti, P.; Celano, G.V.; Bozzo, G. Evaluation of the animal welfare during religious slaughtering. Ital. J. Food Saf. 2020, 9, 39-43. [CrossRef] [PubMed]

49. Bozzo, G.; Barrasso, R.; Marchetti, P.; Roma, R.; Samoilis, G.; Tantillo, G.; Ceci, E. Analysis of Stress Indicators for Evaluation of Animal Welfare and Meat Quality in Traditional and Jewish Slaughtering. Animals 2018, 8, 43. [CrossRef]

50. Zulkifli, I.; Wakiman, Z.; Sazili, A.Q.; Goh, Y.M.; Jalila, A.; Zunita, Z.; Awad, E.A. Effect of shackling, electrical stunning and halal slaughtering method on stress-linked hormones in broilers. S. Afr. J. Anim. Sci. 2019, 49, 598-603. [CrossRef]

51. Rudy, M.; Żurek, J.; Stanisławczyk, R.; Gil, M.; Duma-Kocan, P.; Zaguła, G.; Rudy, S. Analysis of the impact of determinants of kosherness on the content of macro- and microelements in beef. Food Sci. Nutr. 2019, 7, 3463-3470. [CrossRef]

52. D'Agata, M.; Russo, C.; Preziuso, G. Effect of Islamic ritual slaughter on beef quality. Ital. J. Anim. Sci. 2009, 8, 489-491. [CrossRef]

53. Zuckerman, H.; Mannheim, C.H. Color improvement of kosher beef using sodium ascorbate and erythorbate. J. Muscle Foods 2001, 12, 137-151. [CrossRef]

54. Holzer, Z.; Berry, B.W.; Campbell, A.M.; Spanier, A.M.; Solomon, M.B. Effect of koshering and hydrodynamic pressure on beef colour, odor, and microbial loads. J. Muscle Foods 2004, 15, 69-82. [CrossRef]

55. Beriain, M.J.; Goni, M.V.; Indurain, G.; Sarries, M.V.; Insausti, K. Predicting longissimus dorsi myoglobin oxidation in aged beef based on early post-mortem colour measurements on the carcass as a colour stability index. Meat Sci. 2009, 81, 439-445. [CrossRef]

56. Kołczak, T. Barwa mięsa. Gospodarka Mięsna 2007, 9, 12-16.

57. Ouali, A.; Herrera-Mendez, C.H.; Coulis, G.; Becila, C.; Boudjellal, A.; Aubry, L.; Sentandreu, M.A. Revisiting the conversion of muscle into meat and the underlying mechanisms. Meat Sci. 2006, 74, 44-58. [CrossRef] [PubMed]

58. Kołczak, T. Jakość wołowiny. Żywność. Nauka. Technologia. Jakość 2008, 1, 5-22.

59. CIE. Colorimetry. Publication CIE 15.2; Central Bureau of CIE: Vienna, Austria, 1986.

60. D'amico, P.; Vitelli, N.; Goga, B.C.; Nucera, D.; Pedonese, F.; Guidi, A.; Armani, A. Meat from cattle slaughtered without stunning sold in the conventional market without appropriate labelling: A case study in Italy. Meat Sci. 2017, 134, 1-6. [CrossRef]

61. Bozzo, G.; Di Pinto, A.; Bonerba, E.; Ceci, E.; Mottola, A.; Roma, R.; Celano, G.V. Kosher slaughter paradigms: Evaluation of slaughterhouse inspection procedures. Meat Sci. 2017, 128, 30-33. [CrossRef] [PubMed]

62. Farouk, M.M. Advances in the industrial production of halal and kosher red meat. Meat Sci. 2013, 95, 805-820. [CrossRef] [PubMed]

63. Greenfield, H.; Bouchnick, R. Kashrut and Shechita-The Relationship Between Dietary Practices and Ritual Slaughtering of Animals on Jewish Identity. In Identity Crisis: Archaeological Perspectives on Social Identity, Proceedings of the 42nd Annual Chacmool Archaeology Conference, University of Calgary, Calgary, AB, Canada, 2010; Meyer, L., Engel, N., Pickering, S., Eds.; Chacmool Archaeological Association: Calgary, AB, Canada, 2011; pp. 106-120.

64. Anil, M.H. Religious slaughter: A current controversial animal welfare issue. Anim. Front. 2012, 2, 64-67. [CrossRef]

65. Pozzi, P.S.; Geraisy, W.; Barakeh, S.; Azaran, M. Principles of Jewish and Islamic slaughter with respect to OIE (World Organization for Animal Health) recommendations. Isr. J. Vet. Med. 2015, 70, 3-16.

66. Rosen, S.D. Physiological insights into Shechita. Vet. Rec. 2004, 154, 759-765. [CrossRef] 
67. Hayes, N.S.; Schwartz, C.A.; Phelps, K.J.; Borowicz, K.R.; Maddock-Carlin, K.R.; Maddock, R.J. The relationship between pre-harvest stress and the carcass characteristics of beef heifers that qualified for kosher designation. Meat Sci. 2015, 100, 134-138. [CrossRef]

68. Anil, M.H. Effects of Slaughter Method on Carcass and Meat Characteristics in the Meat of Cattle and Sheep; EBLEX-A Divison of the Agriculture and Horticulture Development Board: Stoneleigh, UK, 2012; pp. 1-73.

69. Blech, Z.Y. Kosher Food Production, 2nd ed.; Willey-Blackwell: Ames, IA, USA, 2009; pp. 1-548.

70. Lytton, T.D. Kosher; Harvard University Press: Cambridge, MA, USA, 2013.

71. Italian National Bioethics Committee. Macellazioni Rituali e Sofferenza Animale; Italian National Bioethics Committee: Rome, Italy, 2003; pp. 91-96.

72. Jay, M.J. Modern Food Microbiology, 4th ed.; Chapman and Hall: New York, NY, USA, 1992.

73. Regenstein, J.M.; Regenstein, C.E. The kosher dietary laws and their implementation in the food industry. Food Technol. 1988, 42, 86-94.

74. Hajmeer, M.N.; Marsden, J.L.; Crozier-Dodson, B.A.; Basheer, L.A.; Higgins, J.J. Reduction of microbial counts at a commercial beef koshering facility. J. Food Sci. 1999, 64, 719-723. [CrossRef]

75. Blackmore, D.K. Differences between sheep and cattle during slaughter. Res. Vet. Sci. 1984, 37, 223-226. [CrossRef]

76. Daly, C.C.; Kallweit, E.; Ellendorf, F. Conventional captive bolt stunning followed by exsanguination compared to shechitah slaughter. Vet. Rec. 1988, 122, 325-329. [CrossRef] [PubMed]

77. Grandin, T. Euthanasia and slaughter of livestock. J. Am. Vet. Med. Assoc. 1994, 204, 1354-1360.

78. EFSA: European Food Safety Authority. Welfare Aspects of Animal Stunning and Killing Methods. Scientific Report of the Scientific Panel for Animal Health and Welfare on a Request from the Commission Related to Welfare Aspects of Animal Stunning and Killing Methods. Available online: https:/ / edepot.wur.nl/ 8308 (accessed on 5 July 2021).

79. Colditz, I.G.; Watson, D.L.; Kilgour, R.; Ferguson, D.M.; Prideaux, C.; Ruby, J.; Kirkland, P.D.; Sullivan, K. Impact of animal health and welfare research within the CRC for Cattle and Beef Quality on Australian beef production. Aust. J. Exp. Agric. 2006, 46, 233-244. [CrossRef]

80. Mounier, L.; Dubroeucq, H.; Andanson, S.; Veissier, I. Variations in meat pH of beef bulls in relation to conditions of transfer to slaughter and previous history of the animals. J. Anim. Sci. 2006, 84, 1567-1576. [CrossRef] [PubMed]

81. Grandin, T. Behavioral agitation during handling of cattle is persistent over time. Appl. Anim. Behav. Sci. 1993, 36, 1-9. [CrossRef]

82. Nakyinsige, K.; Sazili, A.Q.; Zulkifli, I.; Gohc, Y.M.; Abu Bakar, F.; Sabow, A.B. Influence of gas stunning and halal slaughter (no stunning) on rabbits' welfare indicators and meat quality. Meat Sci. 2014, 98, 701-708. [CrossRef] [PubMed]

83. Khattak, J.Z.K.; Mir, A.; Anwar, Z.; Abbas, G.; Khattak, H.Z.K.; Ismatullah, H. Concept of halal food and biotechnology. Adv. J. Food Sci. Technol. 2011, 3, 385-389.

84. Riaz, M.N. Hailing halal. Prep. Foods 1996, 165, 53-54.

85. Riaz, M.N.; Chaudry, M.M. Halal Food Production; CRC Press: New York, USA, 2003; pp. 1-400.

86. Benzertiha, A.; Kierończyk, B.; Rawski, M.; Józefiak, A.; Mazurkiewicz, J.; Józefiak, D.; Messikh, M.S.; Świątkiewicz, S. Cultural and practical aspects of halal slaughtering in food production. Med. Weter. 2018, 74, 371-376. [CrossRef]

87. Bonne, K.; Vermeir, I.; Bergeaud-Blackler, F.; Verbeke, W. Determinants of halal meat consumption in France. Br. Food J. 2007, 109, 367-386. [CrossRef]

88. General Guidelines for Use of the Term “HALAL". CAC/GL-24-1997. Available online: http:/ / webcache.googleusercontent. com/search?q=cache:cOqXJqhI7t4J:www.fao.org/input/download/standards/352/CXG_024e.pdf $+\& c d=1 \&$ hl=pl\&ct=clnk\& gl=pl\&client=safari (accessed on 5 July 2021).

89. Department of Standards Malaysia. Halal Food—Production, Preparation, Handling and Storage-General Guidelines (First Revision). Malaysian Standard MS 1500:2004. Available online: https://firatozel.files.wordpress.com/2011/08/halal-foodmalaysian-standard.pdf (accessed on 5 July 2021).

90. Department of Standards Malaysia. Halal food-Production, Preparation, Handling and Storage-General Guidelines (Second Revision). Malaysian Standard MS 1500:2009. Available online: https://law.resource.org/pub/my/ibr/ms.1500.2009.pdf (accessed on 5 July 2021).

91. Wahab, A.R. Guidelines for the Preparation of Halal Food for the Muslim Consumers. Available online: http://www.halalrc.org/ images/Research\%20Material/Literature/halal\%20Guidelines.pdf (accessed on 5 July 2021).

92. Aidaros, H. Global perspectives-The Middle East: Egypt. Rev. - Off. Int. Epizoot. 2005, 24, 589-596.

93. Islam, M.N.; Islam, M.S. Human-animal relationship: Understanding animal rights in the Islamic ecological Paradigm. J. Study Relig. Ideol. 2015, 14, 96-126.

94. Fuseini, A.; Knowles, T.G.; Hadley, P.J.; Wotton, S.B. Halal stunning and slaughter: Criteria for the assessment of dead animals. Meat Sci. 2016, 119, 132-137. [CrossRef]

95. Norma Krajów Rady Współpracy Zatoki Perskiej GS 993/1998. Wymogi dotyczące uboju zwierząt zgodnie z zasadami prawa islamu. Available online: https:/ / webcache.googleusercontent.com/search?q=cache:E9sE4rQz480J:https:/ / www.wetgiw.gov. pl/download/1851_993_1998_PL_uboj-zwierzat,297.pdf+\&cd=1\&hl=pl\&ct=clnk\&gl=pl\&client=safari (accessed on 5 July 2021).

96. Drath, J. Ubój rytualny w polskim systemie prawnym. Colloquium Wydziału Nauk Humanistycznych i Społecznych Kwartalnik 2015 3, 71-86. 
97. Grandin, T. Discussion of Research that Shows that Kosher or Halal Slaughter without Stunning Causes Pain. Available online: https:/ / www.grandin.com/ritual/slaughter.without.stunning.causes.pain.html (accessed on 1 June 2021).

98. Bogardus, E.S. The Relation of Fatigue to Industrial Accidents. Am. J. Sociol. 1911, 17, 351-374. [CrossRef]

99. Imlan, J.C.; Kaka, U.; Goh, Y.M.; Idrus, Z.; Awad, E.A.; Abubakar, A.A.; Ahmad, T.; Nizamuddin, H.N.Q.; Sazili, A.Q. Effects of slaughter knife sharpness on blood biochemical and electroencephalogram changes in cattle. Animals 2020, 10, 579-595. [CrossRef] [PubMed]

100. Aghwan, Z.A.; Bello, A.U.; Abubakar, A.A.; Imlan, J.C.; Sazili, A.Q. Efficient halal bleeding, animal handling, and welfare: A holistic approach for meat quality. Meat Sci. 2016, 121, 420-428. [CrossRef] [PubMed]

101. Gregory, N.G.; von Wenlawowicz, M.; von Holleben, K.; Fielding, H.R.; Gibson, T.J.; Mirabito, L.; Kolesar, R. Complication during shechita and halal slaughter without stunning in cattle. Anim. Welf. 2012, 21, 81-86. [CrossRef]

102. Velarde, A.; Rodriguez, P.; Dalmau, A.; Fuentes, C.; Llonch, P.; Holleben, K.V.; Cenci-Goga, B.T. Religious slaughter: Evaluation of current practices in selected countries. Meat Sci. 2014, 96, 278-287. [CrossRef]

103. The Recognized Foreign HALAL Certification Bodies \& Authorities. Available online: http://www.halal.gov.my/v4/images/ pdf/cb020115.pdf (accessed on 1 June 2021).

104. Farouk, M.M.; Pufpaff, K.M.; Amir, M. Industrial halal meat production and animal welfare: A review. Meat Sci. 2016, 120, 60-70. [CrossRef] [PubMed]

105. Gregory, N.G.; Schuster, P.; Mirabito, L.; Kolesar, R.; McManus, T. Arrested blood flow during false aneurysm formation in the carotid arteries of cattle slaughtered with and without stunning. Meat Sci. 2012, 90, 368-372. [CrossRef] [PubMed]

106. Muhammad, R. Re-branding Halal. Halal J. 2007, 3, 32-34.

107. Marzuki, S.Z.S.; Yunus, N.K.M.; Yazid, Z.N.A.; Ismail, I.R. The Anatomy of Halal Slaughtering: Issues and Challenges; Universiti Teknologi MARA Pahang: Pahang, Malaysia, 2012.

108. Yardimci, M. Comparison of the Stunning and Non-Stunning Slaughtering Methods in the Light of the Current Knowledge. J. Vet. Anim. Res. 2019, 2, 1-5.

109. Gibson, T.J.; Oliveira, S.E.O.; Costa, F.A.D.; Gregory, N.G. Electroencephalographic assessment of pneumatically powered penetrating and non-penetrating captive-bolt stunning of bulls. Meat Sci. 2019, 151, 54-59. [CrossRef]

110. Newhook, J.C.; Blackmore, D.K. Electroencephalographic studies of stunning and slaughter of sheep and calves: Part 1-The onset of permanent insensibility in sheep during slaughter. Meat Sci. 1982, 6, 221-233. [CrossRef]

111. Gregory, N.G.; Wotton, S.B. Sheep slaughtering procedures. II. Time to loss of brain responsiveness after exsanguinations or cardiac arrest. Br. Vet. J. 1984, 140, 354-360. [CrossRef]

112. Rodriguez, P.; Velarde, A.; Dalmau, A.; Llonch, P. Assessment of unconsciousness during slaughter without stunning in lambs. Anim. Welfare 2012, 21, 75-80. [CrossRef]

113. Hopkins, D.L.; Shaw, F.D.; Baud, S.; Walker, P.J. Electrical currents applied to lamb carcasses_Effects on blood release and meat quality. Aust. J. Exp. Agric. 2006, 46, 885-889. [CrossRef]

114. Kirton, A.H.; Frazerhurst, L.F.; Woods, E.G.; Chrystall, B.B. Effect of electrical stunning method and cardiac arrest on bleeding efficiency, residual blood and blood splash in lambs. Meat Sci. 1981, 5, 347-353. [CrossRef]

115. Bager, F.; Braggins, T.J.; Devine, C.E.; Graafhuis, A.E.; Mellor, D.J.; Tavener, A.; Upsdell, M.P. Onset of insensibility at slaughter in calves: Effects of electroplectic seizure and exsanguination on spontaneous electrocortical activity and indices of cerebral metabolism. Res. Vet. Sci. 1992, 52, 162-173. [CrossRef]

116. Grandin, T.; Regenstein, J.M. Religious slaughter and animal welfare: A discussion for meat scientists. Meat Focus Int. 1994, 3 , 115-123.

117. Gomes Neves, J.E.; Paranhos da Costa, M.J.R.; Roca, R.; Gregory, N.G.; Faucitano, L. Comparison of slaughter methods with or without previous stunning on animal welfare and bleeding efficiency in bulls. J. Anim. Sci. 2009, 87 (Suppl. 2), 6.

118. Önenç, A.; Kaya, A. The effects of electrical stunning and percussive captive bolt stunning on meat quality of cattle processed by Turkish slaughter procedures. Meat Sci. 2004, 66, 809-815. [CrossRef] 